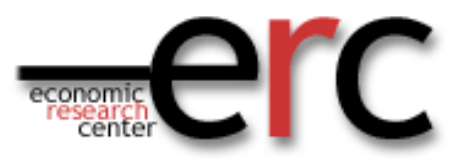

ERC Working Papers in Economics 04/14 October 2004

\title{
Current Account Deficits, Macroeconomic Policy Stance and Governance: An Empirical Investigation
}

\author{
Erdal Özmen \\ Department of Economics \\ Middle East Technical University \\ Ankara 06531 Turkey \\ ozmen@metu.edu.tr
}




\title{
CURRENT ACCOUNT DEFICITS, MACROECONOMIC POLICY STANCE AND GOVERNANCE: AN EMPIRICAL INVESTIGATION
}

\author{
Erdal Özmen \\ Middle East Technical University \\ Department of Economics, 06531, Ankara, Turkey \\ E-mail: ozmen@metu.edu.tr
}

\begin{abstract}
This paper empirically investigates the effects of institutional and macroeconomic policy stance variables on current account deficits (CAD). Based on cross-section data for a broad number of developing and industrial countries, the results strongly suggest that better governance increases whilst the presence of original sin decreases the ability of an economy to sustain CAD. Exchange rate flexibility and openness appear to put a discipline on CAD. Consistent with the equity home bias and Feldstein-Horioka puzzle, $C A D$ decrease with country size. The net impacts of the financial deepening and monetary credibility on CAD are found to be insignificant.
\end{abstract}

Keywords: Current Account, Exchange Rate Regimes, Original Sin, JEL Classification: F32, F41 


\section{INTRODUCTION}

The determinants of current account deficits (CAD) are now at the centre of international macroeconomics with the recent experience of large imbalances of a number of countries including the U.S. The empirical literature appears to focus on the determinants and sustainability of CAD in individual countries or the consequences of it in a cross-section of countries. One strand of the literature focuses on the theory and empirics of the intertemporal approach to the balance of payments (Obstfeld and Rogoff, 1995) according to which CAD is the outcome of forward-looking dynamic saving and investment decisions (Ventura, 2003 and Nason and Rogers, 2003). A related literature considers the Feldstein and Horioka (1980) puzzle of persistent saving-investment correlation (the very small size of CAD) in spite of policy regime changes towards international capital mobility and flexible exchange rates (Coakley, Fuertes and Spagnolo, 2004; Özmen and Parmaksız, 2003 and Taylor, 2003). The recent experience of the U.S. with high deficits appears to be spawning the literature on CAD sustainability (Obstfeld and Rogoff, 2004). Another strand of the literature focuses on the causes and consequences of CAD reversals or sudden stops especially in developing countries (Calvo, Izquierdo and Talvi, 2003 and Edwards, 2004).

Despite their potentially crucial importance in determining the ability of a country to sustain a CAD, macroeconomic policy stance and institutional variables are considered by only a very limited number of studies with Calderon, Chong and Loayza (2002) and Chinn and Prasad (2003) providing two of the most recent exceptions. The objective of this paper is to investigate empirically the roles of such variables including "original sin", exchange rate regimes, rule of law, financial development and monetary credibility in determining the current account positions of a broad number of industrial and developing countries.

The present international financial system allows only a very small number of countries to borrow in their own currencies internationally. This fact is referred to as "original sin" by Eichengreen and Hausmann (1999). Original sin has crucially important theory and policy implications. As Eichengreen et al. (2003) and Hausmann and Panizza (2003) convincingly argue, original sin can lead to financial fragility, greater output and capital flow volatility, lower credit ratings, and limited ability to implement an independent monetary policy. Obstfeld (2004) notes that original sin leads to a harsher macroeconomic adjustment process. All these and the fact that liability dollarization increases the country's vulnerability to sudden stops in capital flows (Calvo et al. 2003) can plausibly lead to many countries to be more prudent about CAD. Thus, the presence of original sin can decrease the ability countries to sustain high levels of CAD.

Exchange rate regime flexibility can increase the capacity of a country to accommodate external shocks (Milesi-Ferretti and Razin, 1996 and Edwards, 2004). Fixed exchange rate regimes can lead to high and often unsustainable CAD due to real exchange rate appreciation. Exchange rate flexibility, on the other hand, can act as a disciplining device on CAD by allowing exchange rates to adjust to CAD disequilibrium. 
Country size plays an important role in international finance as recently argued by Martin and Rey (2004). The menu of financial assets is wider in larger countries leading to a higher equity home bias. Higher equity home bias, in turn, means that the bulk of domestic saving is retained home to finance investment, leading to a lower saving-investment gap and hence a lower CAD.

The level of financial development is important both on savings and investments, and thus on CAD. The net effect of it, however, may not be unambiguous. According to McKinnon and Shaw postulation financial deepening can increase both saving and investment via efficient allocation of resources. Financial development and integration leads to higher CAD according to Blanchard and Giavazzi (2002) as it increases consumption via loosening liquidity constraints and allowing for consumption smoothening. The net impact of financial development on CAD thus appears to be an empirical issue as noted by Chin and Prasad (2003).

In the absence of a credible monetary policy framework, we may expect that inflation is high and real exchange rate is more volatile. The lack of a monetary policy credibility may correspond also to a higher degree of real exchange rate misalignment and thus to a lower level of sustainable CAD. A credible monetary policy can be expected not to let aggregate demand deviate substantially and systematically from the level consistent with the inflation target. In this context, monetary credibility can act as a disciplining device on CAD by responding to aggregate demand shocks. However, the overall impact of monetary credibility and price stability on CAD may not be unambiguous as it can also lead to higher investment and saving via decreasing uncertainty and better resource allocation.

The importance of institutions and governance is well established in the growth literature (Rodrik, 2004 and Kaufmann, 2004) but yet to be explicitly considered in studies on CAD. Better governance and institutions can increase the ability of countries to sustain higher levels of CAD at least via promoting foreign direct investments. In the same context, better governance and institutions can decrease equity home bias abroad as recently argued by Ahearne, Griever and Warnock (2004), and hence increase CAD.

Countries that are more open to international trade can be expected to have larger export sectors enabling them to service external debt more easily and sustaining a higher level of CAD. According to Milesi-Ferretti and Razin (1996) a more open economy is more vulnerable to external shocks. Openness, on the other hand, can make adjustment to sudden stops less painful (Calvo et al., 2003 and Edwards, 2004). The net effect of openness on CAD appears to be ambiguous as noted by Calderon et al. (2002, p. 3).

\section{DATA AND MEASUREMENT ISSUES}

We consider the following measure of original sin (OSIN) for country $i$ developed by Eichengreen, Hausmann and Panizza (2003a,b) based on the Bank for International Settlements (BIS) data on the stock of international debt securities: 


$$
\operatorname{OSIN}_{i}=\max \left(1-\frac{\text { Securities in currency } \mathrm{i}}{\text { Securities issued by country } \mathrm{i}}, 0\right)
$$

For country $\mathrm{i}, \mathrm{OSIN}_{\mathrm{i}}$ is zero if all the securities are issued in its own currency and 1 if they are issued in foreign currency.

For the level of financial development (FIN_DEV) we use the ratio of liquid liabilities to GDP as a proxy variable. As noted by Beck, DemirgüçKunt, and Levine (2000) this is the broadest available indicator of financial intermediation and a typical measure of financial depth. For rule of law and governance, we consider the rule of law $(R L)$ index compiled by Kaufmann, Kraay and Mastruzzi (2003). The $R L$ index ranges from around -2.5 to around 2.5 with higher or positive value indicate greater rule of law and better governance.

The conventional classification of exchange rate regimes is provided by the IMF which is "de iure" that is, it is essentially based on what the countries say that they do. However, actual behaviour may be substantially different from the announced one, therefore it may be preferable to consider de facto regimes rather than the de jure ones. In this study, exchange rate regime (ERR) variable is based on the de facto exchange rate classification by Reinhart and Rogoff (2004). Reinhart and Rogoff (2004) classifies de facto exchange rate regimes on a $1-14$ scale, with higher values denoting more flexible exchange arrangements.

We use the log of the IMF quota as a proxy for each country's economic SIZE. As noted by IMF (2003, p.1) "a member's quota is broadly determined by its economic position relative to other members" and "a variety of economic factors is considered in determining changes in quotas, including GDP, current account transactions, and official reserves".

Inflation rate (INF) can be interpreted as an indicator of the lack of monetary credibility. Thus, monetary credibility variable (MON_CRED) is proxied as the negative of $\log (\mathrm{INF})$. The degree of openness to international trade (OPEN) is defined as the ratio of imports plus exports over the country's GDP.

The sample size for the study is effectively restricted by the availability of original sin (OSIN) measures provided by Eichengreen et al. (2003). As it appears to be highly persistent with an extremely limited time variation, we consider the 1999-2001 average values of OSIN. Consequently, we consider the 1999-2001 averages of CADY (CAD/GDP), OSIN, ERR, OPEN and FIN_DEV. We use the 2000 values of $R L$ and the 1993-2001 average of MON_CRED (taking into account the fact that gaining credibility takes time). All the data except OSIN, RL, SIZE, and ERR are from the World Bank World Development Indicators data base. The data for OSIN, RL, SIZE and ERR are from Eichengreen et al. (2003), Kaufmann et al. (2003), IMF(2003) and Reinhart ve Rogoff (2004), respectively. 


\section{EMPIRICAL RESULTS}

Table 1 reports the results of the models to explain the cross-country ${ }^{1}$ evolution of current accounts where the dependent variable (CADY) is the ratio of CAD over GDP. It may plausibly be argued that the macroeconomic policy stance variables are potentially endogenous for the evolution of CAD. We address the simultaneity issue by estimating the equation also by Generalized Instrumental Variable Estimation (GIVE) method. The second column of Table 1 reports the GIVE results with the instrument set containing $\mathrm{OSIN}_{93-98}, \quad \mathrm{CAD}_{93-98}, \quad \mathrm{OPEN}_{93-98}, \quad \mathrm{ERR}_{93-98}, \quad$ FIN_DEV $93-98, \quad$ LGDP $_{93-98}$, MON_CRED ${ }_{93-98}$, SIZE, RL where the subscripts denote the sample period averages of the corresponding variables and LGDP is the log. of the PPP based GDP. The Sargan test for the equation support the validity of the instrument set. The estimated equations in the table pass all the diagnostics suggesting their empirical validity. The results by the OLS and GIVE are essentially the same for all the variables except MON-CRED supporting that the OLS coefficients are not significantly attenuated by a simultaneity bias.

The presence of original sin appears to restrict the ability of countries to sustain CAD as suggested by the significant and negative coefficient of OSIN in the equations. The lack of international markets to borrow in their own currencies can be interpreted as leading the bulk of countries to be more prudent about CAD to avoid a harsher macroeconomic adjustment process. Redemption from original sin needs a new international financial system as argued by Eichengreen et al. (2003). A decrease in the degree of original sin increases the ability of countries to sustain higher CAD. Thus, the reform of the international financial system to allow complete markets for currencies of countries with sound institutions and macroeconomic conditions can be expected to promote also international trade.

Better governance and institutions increase the ability of countries to sustain higher levels of $C A D$ as suggested by the significant positive coefficient of $R L$ in the equations. This result is consistent with an argument that better governance promotes foreign direct investments and growth (Kaufmann, 2004). Furthermore, better governance and institutions in a country can decrease equity home bias abroad (Ahearne, Griever and Warnock, 2004 and Greenspan, 2004) promoting foreign savings to finance domestic investments and thus increasing sustainable $C A D^{2}$.

${ }^{1}$ The sample contains the following 79 countries: Argentina, Australia, Austria, Bahamas, Bahrain, Barbados, Belgium, Bolivia, Brazil, Bulgaria, Canada, Chile, China, Colombia, Costa Rica, Cyprus, Czech Rep., Denmark, Dominican Rep., Ecuador, Egypt, El Salvador, Estonia, Finland, France, Germany, Ghana, Greece, Guatemala, Hungary, Iceland, India, Indonesia, Ireland, Israel, Italy, Jamaica, Japan, Jordan, Kazakhstan, Kenya, Latvia, Lithuania, Luxembourg, Malaysia, Malta, Mauritius, Mexico, Moldova, Morocco, Netherlands, New Zealand, Norway, Pakistan, Panama, Peru, Philippines, Poland, Portugal, Romania, Russia, S. Africa, S. Korea, Singapore, Slovakia, Slovenia, Spain, Sri Lanka, Suriname, Sweden, Switzerland, Thailand, Tunisia, Turkey, U.K., U.S., Ukraine, Uruguay, Venezuela.

\footnotetext{
${ }^{2}$ This result is quite consistent with Greenspan's (2004, p. 4) interpretation of U.S. CAD as a result of decreasing home bias abroad: "The decline in home bias probably reflects an increased international tendency for financial systems to be more transparent, open, and supportive of strong investor protection. ... Accordingly, the trend of declining home bias and expanding international financial intermediation will likely continue. This process has enabled
} 
CAD appear to decrease as the relative SIZE of the economy increases. Consistent with the Feldstein and Horioka (1980) puzzle, domestic saving-investment link tends to be stronger in larger countries leading to lower CAD. This result strongly supports also Martin and Rey (2004) that country size is important in international finance. Furthermore, larger countries can plausibly expected to have larger and potentially more efficient financial markets leading to a higher domestic saving retention ratio and thus lower CAD. This result is consistent also with the view that the equity home bias, on average, increases with the country size. As already argued, better governance can decrease equity home bias abroad. Considering their relative size in international financial markets, smaller countries can therefore be expected to benefit more by having better governance enabling them to finance higher CAD.

We find a negative and significant relationship between CAD and exchange rate flexibility. The significance of the ERR coefficient improves in the GIVE equation consistent with the potential endogeneity of exchange rate regime for the evolution of CAD. The negative ERR coefficient strongly supports the argument that exchange rate flexibility acts as shock absorber or a disciplining device on CAD by allowing exchange rates to adjust to CAD disequilibrium. This is a consistent result with Edwards (2004, p.1) that "countries with more flexible exchange rate regimes are able to accommodate the shocks stemming from a reversal better than countries with more rigid exchange rate regimes".

Economies more open to international trade tend to have lower CAD supporting the view that openness can make countries more vulnerable to external shocks and crises. This is not necessarily inconsistent with the argument that openness can decrease the magnitude and pain of a real exchange rate adjustment to an external shock or sudden stop (Calvo et al., 2003 and Edwards, 2004). However, the vulnerability effect itself, rather than pain reducing and adjustment smoothening functions of openness appears to be the dominating factor for the fear of CAD.

The levels of financial development and monetary credibility do not significantly affect CAD. The insignificance of the FIN_DEV support the view that financial deepening has positive impact both on savings and investments leading to a statistically neutral effect on the evolution of CAD. Monetary policy credibility can be expected to act as a disciplining device on CAD by responding to aggregate demand shocks not to led them to deviate systematically from the level consistent with the inflation target. The negative coefficient of MON-CRED in the OLS equation supports this view. However, MON_CRED becomes insignificant in the GIVE equation consistent with its endogeneity for the evolution of CAD. The insignificance of MON_CRED for CAD is not surprising not only because of the potential offsetting effects of monetary credibility on saving and investment dynamics but also because of the fact that targeting inflation is much more a credible monetary policy framework than targeting current account.

the United States to incur and finance a much larger current account deficit than would have been feasible in earlier decades". 
The estimated coefficient for $\mathrm{CADY}_{93-98}$ can broadly be interpreted as revealing a high degree of persistence in CAD. This persistence measure, albeit consistent with those obtained in similar studies such as Calderon et al. (2003), should be interpreted with a caution as we consider only averages of two samples with different number of observations.

\section{CONCLUSION}

Current account deficits vary substantially between countries as documented by Ventura (2003) and Edwards (2004). The results of this paper suggest that institutional and macroeconomic policy variables, which are often neglected in the empirical literature, indeed matter for the current account positions of a broad number of industrial and developing countries. The lack of international markets to borrow in their own currencies appears to lead the countries affected from original sin to be more prudent about CAD. Better governance, on the other hand, increases the ability of countries to sustain higher CAD. Flexible exchange rate regimes and openness to international trade can be interpreted as to put a discipline on CAD by providing the necessary adjustment mechanisms. Larger countries with higher equity home bias have higher saving-investment correlations causing lower CAD. Monetary credibility and financial development may be affecting both saving and investment dynamics positively justifying their statistical insignificance for CAD. 


\section{REFERENCES}

Ahearne, A., Griever, W. and F. Warnock (2004) Information Costs and Home Bias: An Analysis of U.S. Holdings of Foreign Equities, Journal of International Economics, March, 313-36.

Beck, T., Demirgüç-Kunt, A. and R. Levine (2000) A New Database on Financial Development and Structure, World Bank Economic Review, 597-605.

Blanchard, O. and F. Giavazzi (2002) Current Account Deficits in the Euro Area: The end of the Feldstein Horioka Puzzle? Brookings Papers on Economic Activity, 2, 147-209.

Calderon, C.A., Chong, A. and N.V. Loayza (2002) Determinants of Current Account Deficits in Developing Countries, Contributions to Macroeconomics, 2(1), Article 2.

Calvo, G.A., Izquierdo, A. and E. Talvi (2003) Sudden Stops, The Real Exchange Rate and Fiscal Sustainability: Argentina's Lessons, NBER Working Paper No. 9828.

Chinn, M.D. and E.S. Prasad (2003) Medium-term Determinants of Current Accounts in Industrial and Developing Countries: An Empirical Exploration, Journal of International Economics, 59, 47-76.

Coakley, J., Fuertes, A. and F. Spagnolo (2004) Is the Feldstein-Horioka Puzzle History?, The Manchester School, 72(5), 569-590.

Edwards, S. (2004) Thirty Years of Current Account Imbalances, Current Account Reversals, and Sudden Stops, IMF Staff Papers, 51, 1-49.

Eichengreen, B., Hausmann, R. and U. Panizza (2003) Currency Mismatches, Debt Intolerance and Original Sin: Why They Are Not the Same and Why it Matters, NBER WP No. 10036.

Feldstein, M.S. ve C.Y. Horioka (1980) Domestic Saving and International Capital Flows, Economic Journal, 90, 314-329.

Greenspan, E. (2004) Current Account, BIS Review, 14, 1-6.

Hausmann, R. and U. Panizza (2003) The Determinants of Original Sin: An Empirical Investigation, Journal of International Money and Finance, 22, 95790.

IMF (2003) IMF Quotas: A Factsheet, IMF.

Kaufmann, D. (2004) Governance Redux: The Empirical Challenge, in Global Competitiveness Report 2003-2004, World Economic Forum

Kaufmann, D., Kraay, A. and M. Mastruzzi (2003) Governance Matters III: Governance Indicators for 1996-2002, World Bank Policy Research Department Working Paper.

Martin, P. and H. Rey (2004) Financial Super-markets: Size Matters for Asset Trade, Forthcoming, Journal of International Economics.

Milesi-Ferretti, G.M. ve A. Razin (1996) Current Account Sustainability, Princeton Studies in International Finance, No. 81.

Nason, J. M. and J. H. Rogers (2002) The Present Value Model of the Current Account Has Been Rejected: Round Up the Usual Suspects, International Finance Discussion Paper No. 760 (Washington: Board of Governors of the Federal Reserve System). 
Obstfeld, M. (2004) Globalization, Macroeconomic Performance, and the Exchange Rates of Emerging Economies, Bank of Japan, IMES Discussion Paper No. 2004-E-14.

Obstfeld M. and K. Rogoff (1995) The Intertemporal Approach to the Current Account, In G. Grossman and K. Rogoff (eds.), Handbook of International Economics, Vol. 3. Amsterdam: North Holland.

Özmen, E. and O.K. Parmaksız (2003) Policy Regime Change and the FeldsteinHorioka Puzzle: The UK Evidence, Journal of Policy Modelling, 25, 137-149.

Pesaran, H.M., ve B. Pesaran (1997) Working with Microfit 4.0, Oxford: Oxford University Press.

Reinhart, C. M. ve K.S. Rogoff (2004) The Modern History of Exchange Rate Arrangements: A Reinterpretation, Quarterly Journal of Economics, Vol. CXIX No. 1, 1-48.

Rodrik, D. (2004) Getting Institutions Right, Mimeo, Harvard University.

Taylor, A.M. (2002) A Century of Current Account Deficits, Journal of International Money and Finance, 21, 725-748.

Ventura, J. (2003) Towards a Theory of Current Account Deficits, World Economy, Vol. 26, 483-512. 
Table 1. The Determinants of Current Account Deficits

\begin{tabular}{|c|c|c|}
\hline & OLS & GIVE \\
\hline Constant & $0.172 * *(4.56)$ & $0.175 * *(3.80)$ \\
\hline OSIN & $-0.044 * *(-2.80)$ & $-0.047 * *(-2.20)$ \\
\hline ERR & $-0.002 *(-1.68)$ & $-0.003 * *(-2.16)$ \\
\hline RL & $0.018 * *(2.76)$ & $0.017 * *(2.30)$ \\
\hline $\begin{array}{l}\text { SIZE } \\
\end{array}$ & $-0.046 * *(-5.09)$ & $-0.036 * *(-3.07)$ \\
\hline FIN_DEV & $0.005(0.96)$ & $-0.012(-0.77)$ \\
\hline MON_CRED & $-0.021 * *(-2.36)$ & $-0.017(-1.44)$ \\
\hline OPEN & $-0.036 * *(-3.90)$ & $-0.034 * *(-3.10)$ \\
\hline $\mathrm{CAD}_{93-98}$ & $0.818 * *(6.61)$ & $0.869 * *(6.17)$ \\
\hline Diagnostics & $\begin{array}{l}\mathrm{R}^{2}=0.67, \text { s.e }=0.034, \mathrm{DW}=2.16, \\
\chi_{\mathrm{SC}}^{2}(1)=0.72[0.40], \chi_{\mathrm{RESET}}^{2}(1)= \\
0.80[0.37], \chi_{\mathrm{HC}}^{2}(1)=0.06[0.80]\end{array}$ & $\begin{array}{l}\mathrm{R}^{2}=0.59, \quad \mathrm{R}_{\mathrm{G}}^{2}=0.67, \text { s.e }=0.038, \\
\mathrm{DW}=2.16, \quad \chi_{\mathrm{SC}}^{2}(1)=0.64[0.42], \\
\chi_{\text {RESET }}^{2}(1)=1.04[0.31], \quad \chi_{\mathrm{HC}}^{2}(1)= \\
0.14[0.71], \quad \chi_{\text {SARGAN }}^{2}(1)=0.06[0.80],\end{array}$ \\
\hline \multicolumn{3}{|c|}{$\begin{array}{l}\text { Notes: The values in parentheses are the t-ratios. * and ** denote the significance at the } 10 \text { and } 5 \% \text {, } \\
\text { respectively. } \mathrm{R}_{\mathrm{G}}{ }^{2} \text { is the generalized } \mathrm{R}^{2} \text { for GIVE. } \chi_{\mathrm{SC}}^{2}(1), \chi_{\text {RESET }}^{2}(1), \chi_{\mathrm{HC}}^{2}(1), \chi_{\mathrm{SARGAN}}^{2} \text { denote } \chi^{2} \\
\text { tests for the null of no serial correlation, no equation mis-specification, homoscedasticity and } \\
\text { instrument set validity, respectively, with p-values given in [.]. See Pesaran and Pesaran (1997) for the } \\
\text { test statistics and GIVE. }\end{array}$} \\
\hline
\end{tabular}

